\title{
Comparison between the United States Soil Conservation Service (SCS) and the two models commonly used for estimating rainfall-runoff in south-eastern Botswana
}

\author{
Rejoice Tsheko \\ University of Botswana, Faculty of Agriculture at B.C.A, Department of Agricultural Engineering and Land Planning, \\ Private Bag 0027, Gaborone, Botswana
}

\begin{abstract}
The United States Soil Conservation Service (SCS) curve number method is used to estimate rainfall runoff from three sub-watersheds in South-Eastern Botswana. This approach uses the NASA Endeavour Shuttle Radar Topography Mission (SRTM) DEMs, digital soil data from the Botswana Ministry of Agriculture, rainfall data from the Department of Meteorological Services and land-use data derived from Landsat ETM+ imagery. Runoff predicted from the SCS method is compared with the runoff calculated using the Pitman and Monash models and the gauged runoff. The Thagale River system watershed produces a mean annual volume of $7.2 \mathrm{Mm}^{3}$ while the Notwane and Metsimotlhabe runoff volumes are $19.9 \mathrm{Mm}^{3}$ and 17.8 $\mathrm{Mm}^{3}$ respectively. The SCS Model is found to be either over- or under-estimating the mean annual runoff volumes found using the other two models. It is concluded that more mean annual runoff volumes should be established for the whole country using the three models and a correlation analysis made in order to determine the superior model. The SCS Model uses a lot of Earth Observation (EO) and other data found in different government departments, hence this encourages collaboration. It is further observed that the SCS Model is quick to produce results, does not require stream gauging and can also easily be updated as the land use/land cover changes.
\end{abstract}

Keywords: Botswana, SCS, curve number, watershed, Dems, soil, rainfall, land use and HEC-1

\section{Introduction}

Botswana is a totally landlocked country lying between latitudes $18^{\circ} \mathrm{S}$ and $27^{\circ} \mathrm{S}$ and longitudes $20^{\circ} \mathrm{E}$ and $29^{\circ} \mathrm{E}$ in Southern Africa. Botswana covers about $528000 \mathrm{~km}^{2}$ with a generally uniform topography varying from $600 \mathrm{~m}$ in the northeast of Tuli Block where the major rivers converge into the Limpopo River, to about a local maxima of $1400 \mathrm{~m}$. Botswana climate is described as arid to semi-arid with generally low and erratic rainfall. Rainfall varies from about $250 \mathrm{~mm}$ in the south-west (Kgalagadi desert) to $650 \mathrm{~mm}$ in the north. The temporal distribution of rainfall within a year is consistent with two distinct seasons namely, a dry winter season extending from May to August and a rainy summer period extending from November to March.

Because of the aridness of the country, the government of Botswana has invested heavily on studies to evaluate potential of water resources in the country. These studies are meant to indicate the water resources that could be developed to meet the ever-increasing water demands for domestic, industrial and agriculture use (BNWMP, 1991; NAMPAD, 2000). The ultimate aim of water resources prediction models must be to improve decision making about a hydrological problem, such as water resources planning, flood protection, mitigation of pollution, or licensing of abstractions (Beven, 2005). It is crucial that the watershed runoff or inflows, which are used as inputs for the modelling of water resources, are accurate as erroneous values could have serious implications.

\footnotetext{
* To whom all correspondence should be addressed.

祍 +267 3650128; fax: +267 3928753;

e-mail: rtsheko@bca.bw
}

Received 19 November 2004; accepted in revised form 26 October 2005.
There are numerous rainfall-runoff models available (lumped or distributed, deterministic or stochastic, fuzzy) (Beven, 2005; Wainwright and Mulligan., 2005). The major constraint to using these models is mainly lack of data (rainfall, rainfall intensity and distribution, discharge data, evapotranspiration losses, water table, soil moisture profiles, spatial patterns of near surface soil moisture, fine resolution digital elevation or terrain maps (DEM and DTM), GIS maps of vegetation types, soil types and geology).

\section{Description of the study area}

Figure 1 shows the map of Botswana; the study area is composed of several small rivers around the city of Gaborone which drain into the Limpopo River.

The objective of this study is to estimate mean annual runoff volumes for South-Eastern Botswana using the SCS Curve Number Model. These mean annual volumes shall then be compared to mean annual volumes determined using the Pitman and Monash models. The river gauge flow data that were used to calibrate the two models for the Notwane and Metsimotlhabe watersheds shall also be compared to the output from the SCS Model.

\section{Watershed}

A watershed is normally defined in terms of the watershed outlet point. Its boundary is defined by identifying all points within an area from which rainfall will contribute water to the outlet. When using a hydrological model, the following watershed characteristics are required; drainage area, watershed or channel length, the shape of the watershed, the slope of the watershed or channel, the drainage pattern, time of flow parameters, land- 


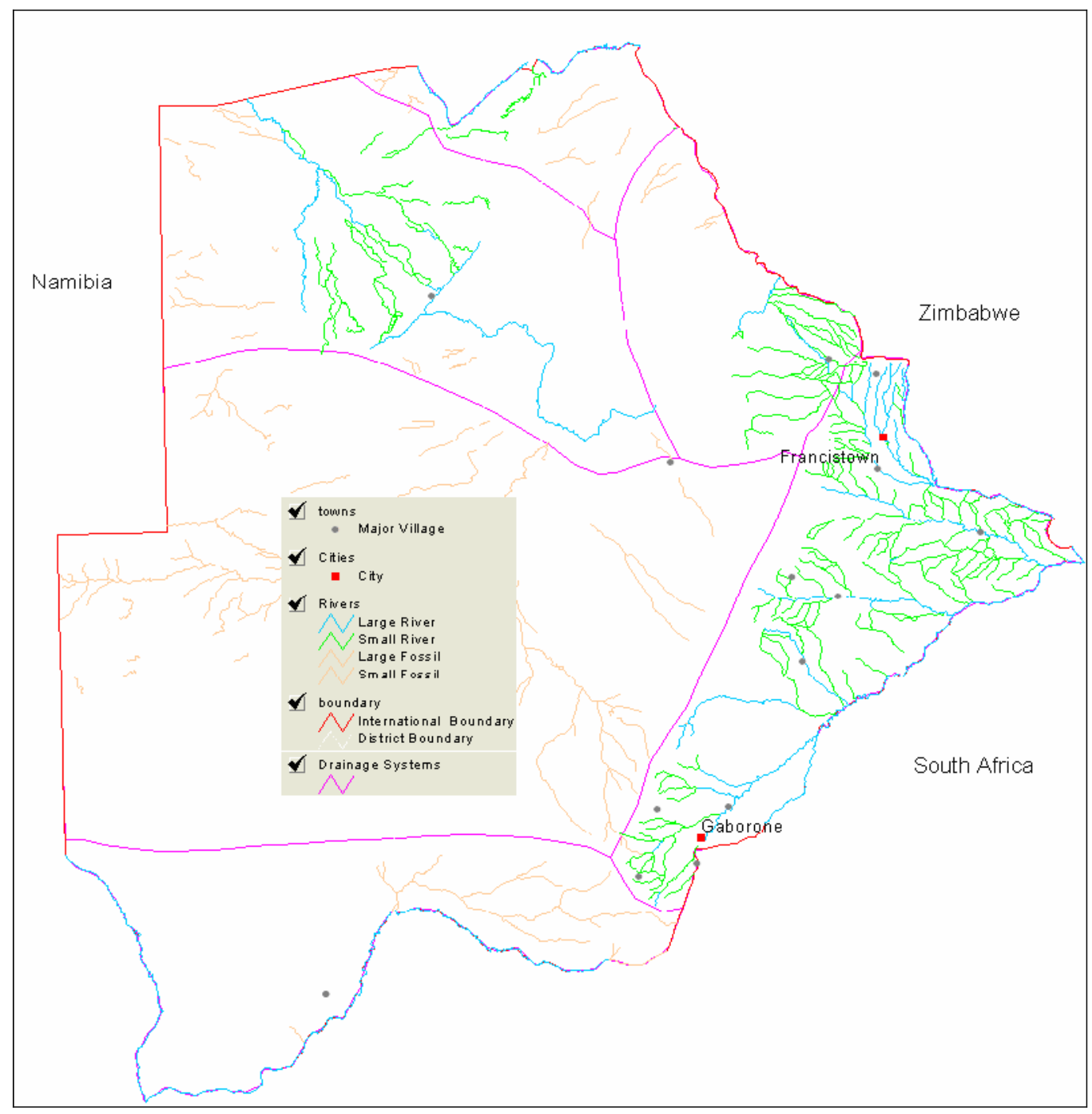

Figure 1

Map of Botswana $(1: 9,460,000)$.

Source: Botswana Atlas

use and hydrological soil types.

In the eastern part of the country, rivers drain in an eastern to north-easterly direction flowing into the left bank of the Limpopo River which forms the international border between Botswana and South Africa. The significant river basins in the study area are the Notwane, Metsimotlhabe and Thagale systems. The total drainage area is $17426 \mathrm{~km}^{2}$. This study area includes the following towns, cities and districts; Gaborone, Lobatse, South East, Kgatleng, Kweneng East, Barolong and Ngwaketsi with a total population of 715959 (CSO, 2001).

\section{Rainfall}

Precipitation is an important element in many engineering designs. Although some designs only require the total volume of rainfall for a specified duration and frequency, many problems in hydrological design require the storm input to the design method to be expressed as a hyetograph (distribution of rain with respect to time) and not just as a total volume of the storm.

The methodology used by United States Soil Conservation Service (SCS) to develop dimensionless rainfall distributions using the Weather Bureau's Rainfall Frequency Atlases, could be used to develop rainfall distributions for Botswana. Gieske (1992) observed that although rainfall amounts of 1987 to 1990 were above average, disregarding $1 \mathrm{~mm}$ or less storm events gave an average runoff depth of $8.5 \mathrm{~mm}$ and storm duration of $3.3 \mathrm{~h}$. He concluded that in general, storm events lasted for less than $24 \mathrm{~h}$ in the Southeastern part of Botswana. Botswana experienced a low total annual rainfall characterised by very short and intense storms covering fairly small areas (Bhalotra, 1985; Gieske, 1992). In Botswana, the majority of runoff- producing storms result from convective thunderstorm-type events. The observation made above has also been seen elsewhere, that is intense storms are not necessarily more frequent in areas of high total annual rainfall (Schwab et al., 1993).

\section{Soils}

Soil functions essentially as a pervious medium that provides a large number of passageways for water to move into the surface. The effectiveness of the soil to transport water depends on the size and permanency of the channels. The size of the conduits depends on the size of the soil particles, the degree of aggregation between particles and the arrangements of particles and aggregates.

The soils of Botswana were mapped under the Soil Mapping and Advisory Services Project of the FAO/UNDP. The different soil units were identified and classified according to the FAO Revised Legends of the Soil Map of the World (FAO, 1988). Measurements of the physical properties of the soil were 
also done for agriculturally important areas including the area in the present study. These physical properties include particle size distribution, bulk density, infiltration characteristics, moisture retention and structural stability of the surface soil (Joshua, 1991). The soils found at the study site include Arenosols, Luvisols, Calcisols, Vertisols, Gleysols and Regosols. Based on infiltration rates, these soils were categorised into four hydrological soil types.

\section{Runoff}

Runoff is the portion of precipitation that makes its way to stream channels, lakes, or oceans as surface or subsurface runoff. In this study only the surface flow is dealt with. Surface runoff will only occur when the rate of precipitation exceeds the rate of water infiltration into the soil. In semi-arid areas such as Botswana, the total runoff is very low due to low rainfall and high transpiration losses. A threshold rainfall of $25 \mathrm{~mm}$ to $35 \mathrm{~mm}$ is required to generate runoff in the South-East of Botswana (BNWMP, 1991).

The Department of Water Affairs (DWA) is responsible for the collection, storage, and dissemination of hydrometric data in Botswana. There are limited available stream discharge measurements for the southeast region. These include the Notwane $4172.4 \mathrm{~km}^{2}$, Metsimotlhabe $3568 \mathrm{~km}^{2}$ and Thagale $9686 \mathrm{~km}^{2}$.

\section{Digital Elevation Model (DEM)}

Digital elevation models and digital terrain maps (DTM) can be used to derive a wealth of information about the morphology of a land surface using algorithms traditionally used for processing raster data (U.S. Geological Survey, 1987; Jenson and Domingue, 1988; Klingebiel et al 1988; Wainwright and Mulligan, 2005). Nowadays DEMs are widely and readily available, these include satellite derived DEMs such as ASTER and SRTM, aerial photography derived DEMs and finally DEMs from digitised contour maps (Beven, 2005; Wentzel, 2002).

In February 2000, the Shuttle Radar Topography Mission (SRTM) successfully collected interferometric synthetic aperture radar (IFSAR) data over 80 per cent of the landmass of the Earth between 60 degrees North and 56 degrees South latitudes to generate the most complete high-resolution digital topographic database of Earth.

SRTM consisted of a specially modified radar system that flew onboard the Space Shuttle Endeavour during an 11-day mission. SRTM is an international project spearheaded by the National Geospatial-Intelligence Agency (NGA) and the National Aeronautics and Space Administration (NASA). These SRTM DEMs are now being distributed by several agencies both public and private at three spatial resolutions.

\section{Land use}

Current land cover is essential information for a reliable environmental database. Land cover is the expression of human activities and as such changes with alteration in these. Hence, land cover is a geographical feature which may form a reference base for applications ranging from forest and rangeland monitoring, production of statistics, planning, investment, biodiversity, climate change, hydrology, to desertification control. Despite the high demand for such type of information in most developing countries, these data are usually missing, outdated or not consistent. There has always been a need to standardise land use/ land cover classification (UNESCO, 1973; Muller et al., 2002;
Anderson et al., 1976), recently FAO, UNEP and UNDP are in the forefront of developing what is known as Global Land Cover Network (GLCN) using the Land Cover Classification System (LCCS) developed during the FAO Africover Project in East Africa.

\section{Research methodology}

\section{Currently used runoff-models}

In the past, the two deterministic rainfall-runoff models utilised in Botswana are the Pitman and Monash Models. The Pitman Model has been applied extensively in water resource projects in Botswana and most of Southern Africa (BNWMP, 1991). This lumped parameter model routes the monthly rainfall to runoff through interception and soil moisture storage, while deducting evaporation and transpiration losses (Pitman, 1973). The Monash Model is a distributed daily model, allowing area variability in rainfall and the catchment's geomorphology to be modelled directly (Porter and McMahon, 1971). BNWMP (1991) concluded that the Monash Model was superior to the Pitman Model and hence it was adopted for water resource planning in Botswana.

In Botswana, the rational formula method has been adopted and is used for small catchments in road design drainage (i.e. less than $25 \mathrm{~km}^{2}$ ). The United States Soil Conservation Service (SCS) Curve Number Method has been found useful for designing catchments (greater than $25 \mathrm{~km}^{2}$ ) in South Africa. Engineers tend to extrapolate data from South Africa when applying the model to the Botswana conditions. BNWMP (1991) concluded that the model parameters for SCS method are lacking in Botswana hence the extrapolation of South Africa data may lead to errors in flood estimation.

A water resources model has been developed for the Botswana conditions; this model integrates surface and groundwater sources of Southeast Botswana (SMEC et al., 1990; BNWMP, 1991). This model uses mostly outputs from the two models named above as inputs.

\section{Soil Conservation Service Model (SCS)}

This method was developed by SCS for uniform rainfall using the assumptions for a triangular hydrograph as shown in Eq. (1). This empirical method was developed from many years of stormflow records from agricultural watersheds in many parts of the United States. To compute runoff for a given precipitation, it is necessary to compute the curve number. A curve number $(\mathrm{CN})$ is an index that represents the combination of a hydrological soil group and land-use and treatment class. A CN is a function of soil group, land-cover complex and antecedent moisture conditions.

$$
Q=\frac{(P-0.2 S)^{2}}{P+0.8 S}
$$

where:

$\mathrm{Q}$ is the runoff depth in $\mathrm{mm}$

$\mathrm{P}$ is the rainfall in $\mathrm{mm}$

$\mathrm{S}$ is the maximum potential difference between rainfall and runoff in $\mathrm{mm}$, starting at the time the storm begins. where:

$$
S=\frac{25400}{C N}-254
$$

and: 
Peak discharge, $\mathrm{q}_{\mathrm{p}}$ can then be computed using Eq.(3) below;

$$
q_{p}=q_{u m} A_{m} Q
$$

where:

$\mathrm{q}_{\mathrm{um}}$ is the unit peak discharge $\left(\mathrm{m}^{3} / \mathrm{s} / \mathrm{km}^{2} / \mathrm{mm}\right)$ of runoff

$\mathrm{A}$ is the drainage area in $\mathrm{km}^{2}$

$\mathrm{Q}$ is the depth of runoff in $\mathrm{mm}$.

\section{Data sources and preparation for the SCS model}

\section{DEM}

The Shuttle Radar Topography Mission (SRTM) DEMs data were acquired from FAO-SDRN. A global DEM was acquired using C-band (SIR-C) and X-band (X-SAR) interferometric synthetic aperture radars (ISAR). This DEM is currently the most complete homogeneous $30 \mathrm{~m}$ and $90 \mathrm{~m}$ resolution of the world (Baghdadi et al., 2005). Given the need for immediate availability of mosaicked and corrected elevation data for its activities and programmes, FAO-SDRN initiated its own program of post-processing raw 3 arc-second SRTM tiles to fulfil the objective of distributing to members of the GLCN network national coverage of base data sets such as elevation and multi-temporal Landsat images. FAOSDRN used two alternative procedures for patching $90 \mathrm{~m}$ SRTM data. Due to superior results, the TOPOGRID algorithm of the ESRI-Arc/Info Model was used to interpolate the SRTM DEMs data and hence fill the gaps (http://srtm.csi.cgiar.org ).

The DEMs for the project area were cropped from the S10E20 SRTM tiles and reprojected to UTM South Zone 35 for further processing using Watershed Modelling System (WMS v7.0) software. Watershed delineation from DEMs using the drainage module of WMS is straightforward and relatively simple. Figure 2 shows the delineated watershed, two reservoirs namely the Gaborone and Bokaa are also shown including several small earth dams constructed for agricultural purposes. The Molatedi Dam shown is in South Africa and also does not fall in the research area.

\section{Soils}

Digital soil data were obtained from the Botswana Ministry of Agriculture. These data comprised 1:100 000 shape and attribute data of the different soil types in Botswana (FAO/UNDP/Government of Botswana). The hydrological soil type attribute was created based on the infiltration rates of the different soil types based on AG: BOT/85/011 Field Document Number 33 (Joshua, 1991). The study site was clipped out of the whole country data using ArcView and reprojected to UTM South Zone 35 for further processing. After the infiltration data was added to the database, Fig. 3 was produced, the light colours show high infiltration sandy soils.

\section{Land use}

Landsat ETM+ data were also acquired from FAO-SDRN and the regional remote sensing unit (RRSU). Channels 1, 3 and 4 of

\section{Figure 3}

Hydrological Soil Types (0 -highest infiltration rate) (1:1 760 000) 


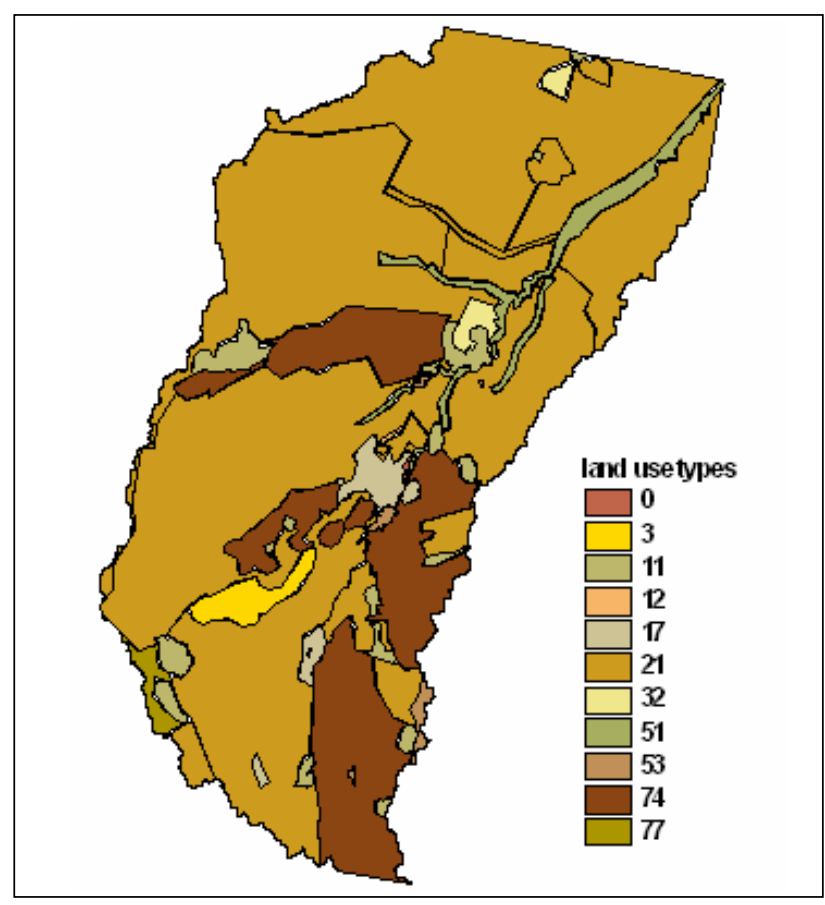

Figure 4

Land-use types (based on Anderson et al., 1976) (1:1 720 000)

the Landsat ETM+ (Path172 Row 077 2002) image were used to create the land-use/ land-cover database (Anderson et al., 1976; Lillesand et al., 2004; The Arkansas GAP Analysis Project). Manual and semi-automatic classification was carried out using GeoVIS software (Hagen and Di Gregorio, 2004; Terra Nova, 2000). The study area land use/ land cover database was clipped out and edited in ArcView and also reprojected to UTM South Zone 35 for further processing. Twelve land-use types were identified as shown in Fig. 4.

\section{Rainfall}

In this study, the procedure outlined in McCuen (1989) was used to develop dimensionless rainfall distributions for the study area using Gaborone rainfall data from the department of Meteorological Services (DMS). Rainfall actual and generated (BNWMP, 1991) data from 8 stations in the Notwane, 10 stations in the Metsimotlhabe and 9 stations in the Thagale river systems were used to calculate average rainfall data input into the HEC-1 (Hydrological Engineering Center-routine1) model. From the long-term rainfall data (1925 to 1988), the average rainfall for the winter months (June, July and August) is less than $5 \mathrm{~mm}$ per month, which is very little to produce any runoff in the SCS Model. These months were excluded in the analysis; hence only nine monthly data runoff volumes were calculated. In addition to the mean data, extreme conditions

Figure 6 (right) Methodology flowchart

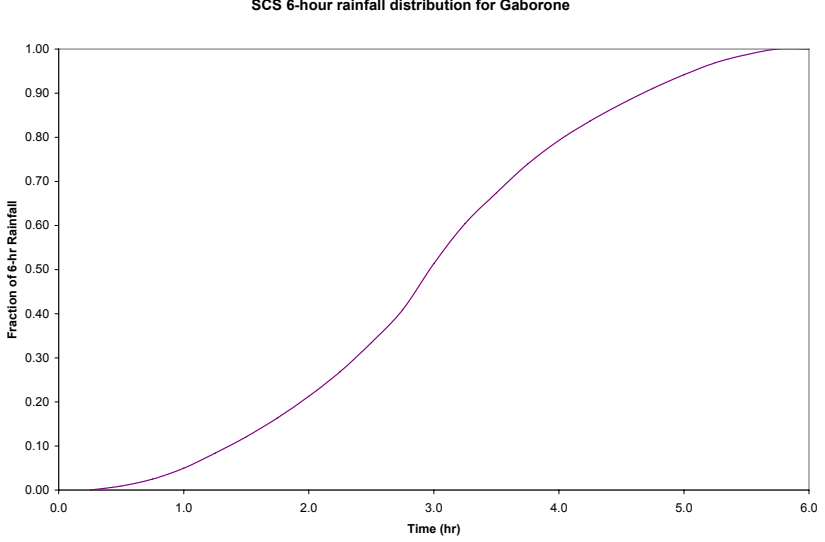

Figure 5

A cumulative rainfall curve

such as long-term minimum and maximum data were also simulated. Figure 5 shows the developed dimensionless rainfall distribution data for Gaborone used by the model.

\section{SCS model results}

\section{Composite curve numbers}

The land-use and soil data were used to calculate composite curve numbers for the watersheds. The shape files were mapped to WMS feature objects using the GIS module. The soils coverage shapefile was mapped to HYDGRP (hydrological soil group) and the land-use coverage shape file mapped to LUCODE (land-use code). These are field names created in the database to store hydrological soil group and land-use codes in the watershed model (WMS) after GIS overlay. The mapping table were prepared and saved earlier in text mode. Finally the hydrological modelling module was used to calculate the composite curve numbers.

Figure 6 summarises the data integration methodology, showing the raw data, processing steps and tools, SCS model inputs and expected output from the model.

The HEC-1 model was used to calculate runoff for the three sub basins as shown in Fig. 7.

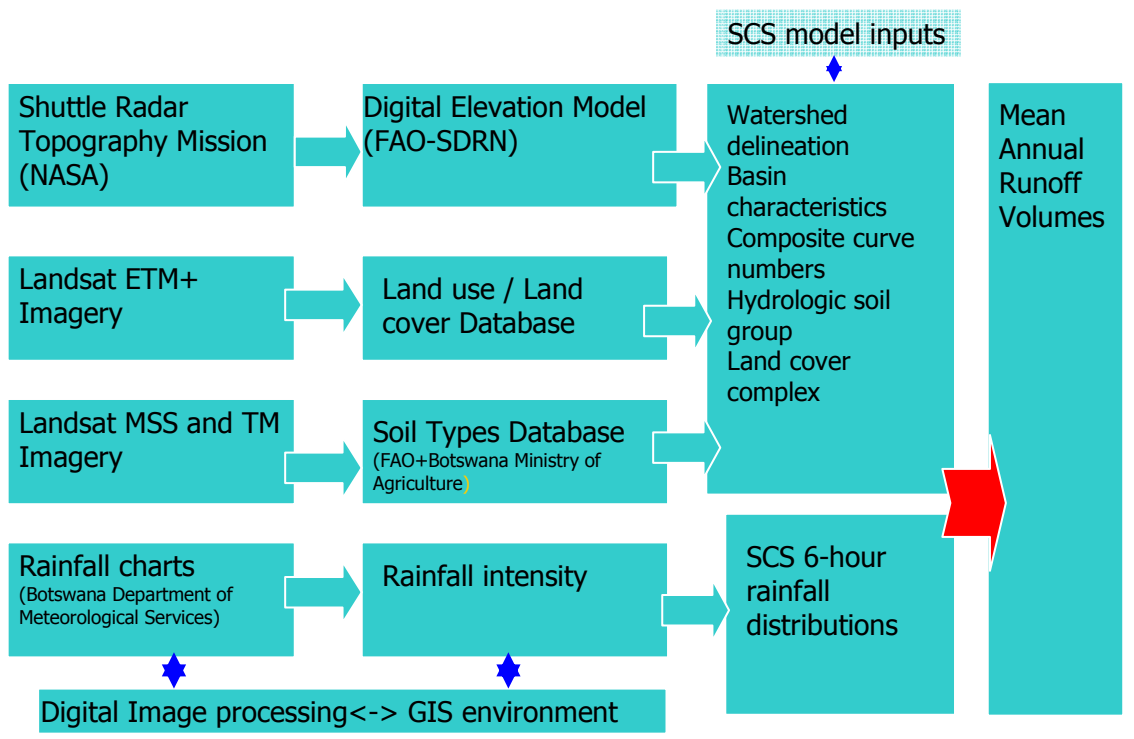




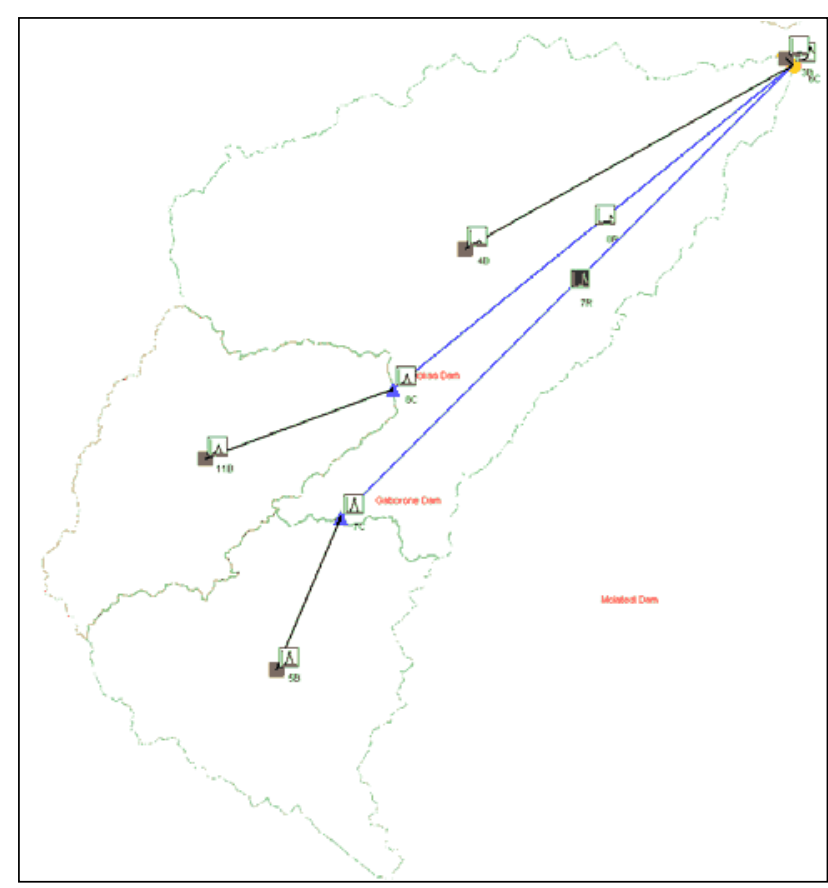

Figure 7

HEC-1 model layouts for the three sub-basins $(1: 1,920,000)$

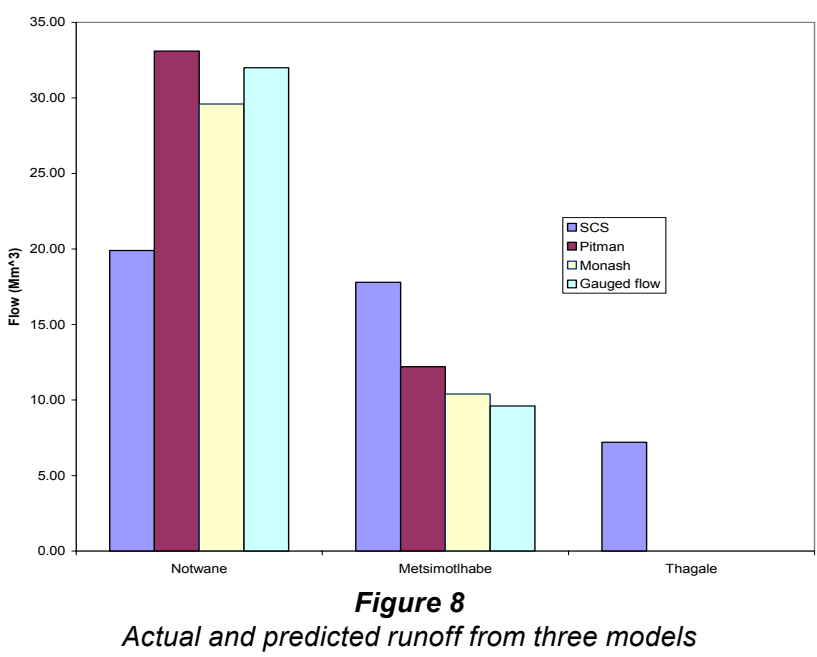

\section{Runoff predictions}

Figure 8 shows the potential runoff using the Pitman, Monash (BNWMP, 1991) and SCS Models. Based on the gauged runoff data, the SCS method underestimates the runoff values for the Notwane River system watershed by $37.8 \%$ while overestimating the runoff values for the Metsimotlhabe River system by $53.9 \%$. The Thagale River system runoff is calculated to be $7.2 \mathrm{Mm}^{3}$ using the SCS method; it has not been estimated previously.

The SCS method estimated mean annual runoff value for Notwane watershed is $67 \%$ of the value adopted by (BNWMP, 1991) using the Monash model. This model also gives a runoff value $71 \%$ more than the Metsimotlhabe watershed value found using the Monash model.

\section{Discussion and evaluation}

Using the DEMs to delineate watersheds gave $4172.4 \mathrm{~km}^{2}$ for the Notwane River system, $3568 \mathrm{~km}^{2}$ for the Metsimotlhabe
River system and $9686 \mathrm{~km}^{2}$ for the Thagale River system. This compares very well with already established figures of $3983 \mathrm{~km}^{2}$ and $3570 \mathrm{~km}^{2}$ for both the Notwane and Metsimotlhabe River systems (BNWMP, 1991). There is, however, $4.8 \%$ difference in the watershed size for the Notwane River system. The Thagale River system, which includes Monametsana, Makgobokgobo and Mosomane has a huge drainage area but the curve number is only 56.15. This area is composed of mostly deep sands as shown in the soil map hence runoff is very small. There are several reasons to explain the variations in the mean annual runoff from the three models. There had been concerns on the availability and quality of stream flow records data (BNWMP, 1991); there are difficulties in recording water levels and inaccuracies in the adopted rating curves. There are very few stream gauged data used to calibrate the Pitman and Monash models. The model parameters required for both the Pitman and Monash are not easily or readily available in Botswana for comparison. No detailed work has been done to neither verify the model parameters nor determine the monthly evapotranspiration in Botswana; a figure based on $2000 \mathrm{~mm} / \mathrm{yr}$ of open water evaporation is normally used. Although (BNWMP, 1991) found the Pitman model not acceptable, this model has been used extensively in the region (Midgley et al., 1994; Okavango Prototype Planning Model Report, 2004). It seems these models are mostly chosen based on preference and not necessarily merit. The overestimation of the Metsimotlhabe River system runoff might be attributed to the fact that Gaborone city runoff does not flow into the Gaborone Dam, which is the outlet for the Notwane watershed, but rather flows into the Metsimotlhabe River system. This runoff bypasses the outlet (Gaborone Dam) via the Segoditshane River, which in this study falls within the Metsimotlhabe watershed. It has to be noted that the gauging station for the Metsimotlhabe watershed is at the Bokaa Dam hence it will not record this flow, which ends up in the Limpopo River. Therefore the runoff from the city of Gaborone bypasses the two reservoirs at the Gaborone Dam and Bokaa Dam.

Previously, the Thagale watershed did not have estimated mean annual runoff volume due to probably lack of gauging stations. It can be seen that the SCS method could be applied rapidly to all the watersheds even those without gauging stations.

Figure 8 also shows that the SCS Model results do not correlate with neither the Pitman nor the Monash models runoff estimations for the Notwane and Metsimotlhabe watersheds. These two models were calibrated with the gauged data; hence it might be necessary to calibrate the SCS Model with the gauged data. Since the SCS Model is sensitive to land-use changes, new-gauged data should be used if calibration is required. The other problem with the calibration procedure for the SCS Model is that this model requires significant data as compared to the two models; hence calibration might negate this advantage. The best approach shall be to collect mean annual runoff volume data for the whole country using all the three models and gauged data where available and then perform a rigorous correlation analysis.

All the runoff occurs within seven months (October to April) as shown in Fig. 9. The other months' rainfall is very little to produce any runoff. The SCS method does not model low rainfall runoff very well; the rainfall has to be at least $30 \mathrm{~mm}$ for higher curve numbers and $40 \mathrm{~mm}$ for lower curve numbers. BNWMP (1991) have also concluded that a threshold rainfall of 25 to $35 \mathrm{~mm}$ is required to produce runoff in the Pitman and Monash Models. 


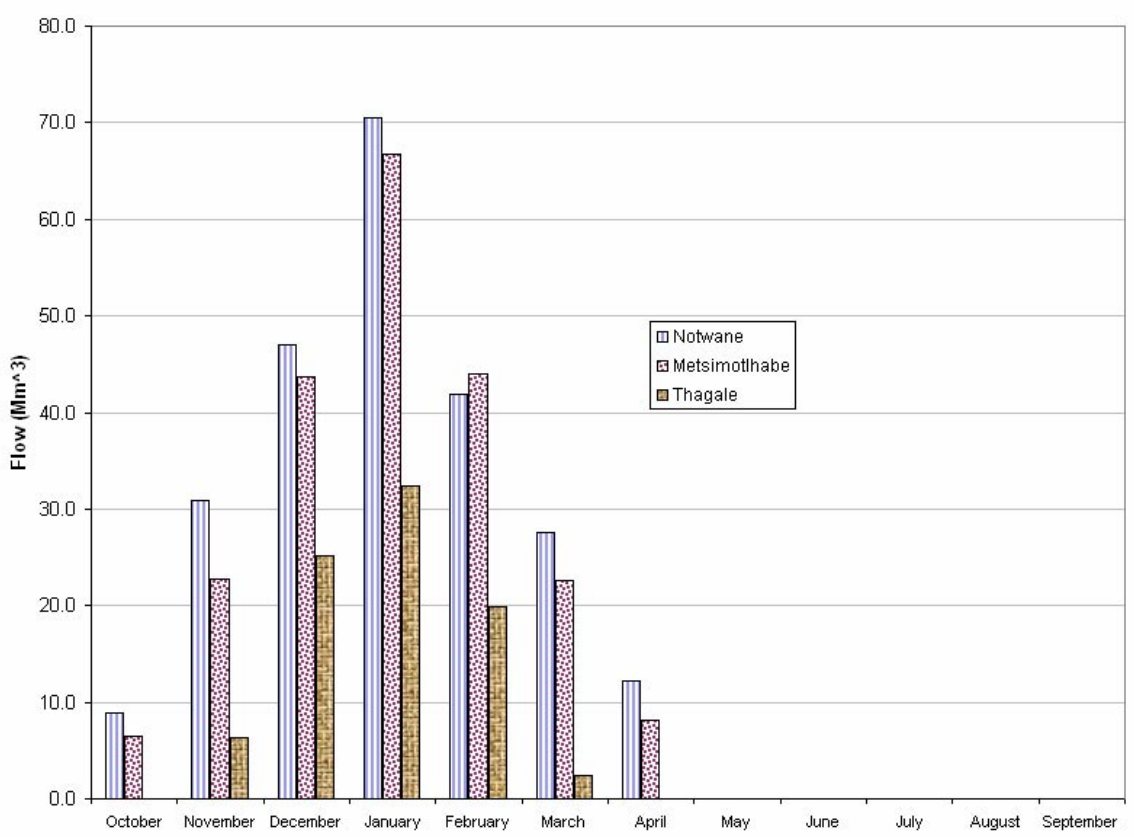

\section{Conclusions}

Rainfall runoff has been estimated for the three river systems watersheds based on 6-h storms. Using the SCS Model, Thagale River system watershed produces a mean annual volume of $7.2 \mathrm{Mm}^{3}$ while the Notwane and Metsimotlhabe runoff volumes are $19.9 \mathrm{Mm}^{3}$ and $17.8 \mathrm{Mm}^{3}$ respectively. Runoff can only be expected between the months of October to April due to rainfall amounts available.

The mean annual runoff volumes estimated using the SCS Model are significantly different from those from the calibrated Pitman and Monash models (Appendix 1). The SCS Model overestimate and underestimate mean annual runoff volumes for Metsimotlhabe and Notwane river systems respectively. The SCS Model can predict runoff volumes for un-gauged watershed as demonstrated for the Thagale watershed. This is an advantage, as most rivers minor systems in Botswana are not gauged. The SCS Model dependence on Earth Observation (EO) is advantageous because run-off volumes can be computed rapidly form digital data and also be updated regularly as land-use/land cover changes. The Departments of Water Affairs, Roads and the Ministry of Agriculture can start using the procedures developed in this study to develop a comprehensive database of mean annual runoff volumes for the whole country. The issue of assessing the appropriate model to be adopted can further be analysed once a significant database has been developed. This study has shown that it is feasible to integrate different digital datasets available in different Government departments to address unique challenges of the semi-arid Botswana.

\section{References}

ANDERSON JR, HARDY EE, ROACH JT AND WITMER RE (1976)

A Land Use and Land Cover Classification System for Use with Remote Sensor Data. Geological Survey Professional Paper 964. US Government Printing Office, Washington, USA.

BAGHDADI N CAVALIER S CHILES JP BOURGINE B TOUTIN TH KING C DANIELS P PERRIN J and TRUFFERT C (2005) Merging of airborne elevation data and Radarsat data to develop a digital elevation model. Int. J. of Rem. Sen. 26 (1) 141-166.

BEVEN KJ (2005) Rainfall-Runoff Modelling, The Primer. John Wiley $\&$ Sons, New York.
BHALOTRA YPR (1985) Rainfall Maps of Botswana. Republic of Botswana, Deartment of Meteorological Services, Gaborone, Botswana.

BNWMP (1991) Hydrology, SMEC, WLPU and SGAB. Final Report, Volume 6. Gaborone, Botswana.

BNWMP (1991) Water Resources Modelling, SMEC. Final Report, Volume 12. WLPU and SGAB. Gaborone, Botswana.

CSO (2000) Botswana Environmental Statistics, Department of Printing and Publishing Services, Gaborone, Botswana.

FAO (1988) Revised Legends of the FAO/UNESCO Soil Map of the World, FAO, Rome, Italy.

GIESKE A (1992) Dynamics of Groundwater Recharge - A Case Study in Semi-Arid Eastern Botswana. Ph.D. Thesis, University of Amsterdam, Amsterdam, the Netherlands.

HAGEN CV and DI GREGORIO A (2004) Using GeoVis and LCCS Manual.GCP/RAF/287/ITA, FAO, Rome, Italy.

JENSON SK and DOMINGUE JO (1988) Extracting topographic structure from digital elevation data for geographic information system analysis. Photogram. Eng. Rem. Sens. 54 (11) 1593- 1600.

JOSHUA WD (1991) Soil Mapping and Advisory Services Botswana. Physical Properties of the Soils of Botswana. AG: BOT/85/011 Field Document 22. FAO.

KLINGEBIEL AA, HORVATH EH, REYBOLD WC, MOORE DG, FOSNIGHT EA and LOVELAND TR (1988) A Guide for the Use of Digital Elevation Model Data for Making Soil Surveys. U.S. Geological Survey Open-File Report No 88-102.

LILLESAND TM, KIEFER RW and CHIPMAN JW (2004) Remote Sensing and Image Interpretation $\left(5^{\text {th }} \mathrm{edn}\right.$.) John Wiley \& Sons, NJ, USA.

McCUEN RH (1989) Hydrologic Analysis and Design. Prentice Hall, Engle Cliffs.

MIDGLEY DC, PITMAN WV and MIDDLETON BJ (1994) Surface Water Resources of South Africa 1990. Vols. I - VI. WRC Reports No. 298/1.1/94 to 198/6.1/94. Water Research Commission, Pretoria, South Africa.

MULLER JL PRETORIUS C and VINK ER (2002) The SADC Land Cover Database Project. Division of Water, Environment and Forestry Technology, CSIR, Pretoria, South Africa.

NAMPAD (2000) Climate, Soils and Water. Final Report, Volume 4., TAHAL Consulting Engineers. Gaborone, Botswana.

OKAVANGO PROTOTYPE PLANNING MODEL REPORT (2004) Sharing Water: Towards a Transboundary Consensus on the Management of the Okavango River. USAID.

PITMAN WV (1973) A Mathematical Model for Generating Monthly River Flow from Meteorological Data in South Africa. University of Witwatersrand, Hydrological Research Unit, Report No. 2/73. 
PORTER JW and MCMAHON TA (1971) A model for the simulation of stream flow records from climatic records. J. Hydrol. 13 (33) 297-324.

PORTER JW and MCMAHON TA (1976)The Monash Model: User Manual for Daily Program HYDROLOG. Dept. of Civil Eng., Monash University, Research Rep. 2/76, 41 pp.

SCHWAB GO, FANGMEIER DD, ELLIOT WJ and FREVERT RK (1993) Soil and Water Conservation Engineering ( $4^{\text {th }}$ edn.). John Wiley and Sons, INC. NY.

SMEC (1990) Sukwane Dam Feasibility/Preliminary Design Study, Final Report. Department of Water Affairs, Gaborone, Botswana.

TERRA NOVA (2000) GeoVIS. Terra Nova Geographic Information Systems, Rome, Italy.

THE ARKANSAS GAP ANALYSIS PROJECT. Land Cover Classification and Mapping. Final Report. Centre for Advanced Spatial
Technologies (CAST). http://www.cast.uark.edu/gap/chap2.htm

US GEOLOGICAL SURVEY (1987) Digital elevation models. U.S Geological Survey. Data User's Guide 5.

UNESCO (1973) International Classification and Mapping of Vegetation. Paris, France. 35 pp.

WAINWRIGHT J and MULLIGAN M. (eds.) (2005) Environmental Modelling: Finding Simplicity in Complexity. John Wiley \& Sons, Ltd. London. UK.

WATERSHED MODELING SYSTEM v7.0 (2002) Brigham Young University - Environmental Modeling Research Laboratory, Provo, Utah.

WENTZEL K (2002) Determination of the overall soil erosion potential in the Nsikazi District (Mpumalanga Province, South Africa) using remote sensing and GIS. Can. J. Rem. Sen. 28 (2) 322-327.

\section{Model parameters for the Pitman and Monash Models}

\begin{tabular}{|l|l|c|c|}
\hline \multicolumn{2}{|c|}{ Monash Model - parameter values (source: BNWMP, 1991) } & $\begin{array}{c}\text { Notwane } \\
\text { River } \\
\text { (Gaborone } \\
\text { Dam) }\end{array}$ & $\begin{array}{c}\text { Metsimotl- } \\
\text { habe River } \\
\text { (Bokaa } \\
\text { Dam) }\end{array}$ \\
\hline Parameter & Description & 275 & 310 \\
\hline COFF $(\mathrm{mm} / \mathrm{d})$ & Maximum daily infiltration & 175 & 175 \\
\hline SMSC $(\mathrm{mm})$ & Soil moisture storage capacity & 3.0 & 3.0 \\
\hline DSC $(\mathrm{mm})$ & Depression storage & 10.0 & 12.0 \\
\hline ADS & Maximum possible daily evaporation rate & 0.1 & 0.1 \\
\hline SUB & Proportion of catchment's draining to depressions & 0.10 & 0.09 \\
\hline CRAK & Maximum proportion of infiltrated moisture directed to interflow under saturated \\
conditions & Maximum proportion of infiltrated moisture directed to ground storage & 0.3 & 0.3 \\
\hline CPDAY & Coefficient in non-linear groundwater storage/discharge relationship & 0.0 & 0.0 \\
\hline ZDAY & Exponent in non-linear groundwater storage/discharge relationship & 0.3 & 0.3 \\
\hline ALEAK & Fraction of groundwater storage lost daily & 0.0 & 0.0 \\
\hline SQ & Exponent in relationship between infiltration sensitivity and soil moisture status & 3.0 & 1.5 \\
\hline CO (hour) & Storage-delay coefficient for runoff routing & 8 & 8 \\
\hline RFMIN (mm) & Daily rainfall total below which all rainfall infiltrates & 25 & 35 \\
\hline SEAS & $\begin{array}{l}\text { Half amplitude of cycle, expressed as a fraction of the mean value of the seasonal } \\
\text { parameters }\end{array}$ & 0.30 & 0.50 \\
\hline LOCAT (month) & Month of start cycle of seasonally adjusted parameters & 9 & 8 \\
\hline
\end{tabular}

\begin{tabular}{|l|l|c|c|}
\hline \multicolumn{3}{|c|}{ Pitman model - parameter values (source: BNWMP, 1991) } \\
\hline Parameter & Description & $\begin{array}{c}\text { Notwane River } \\
\text { (Gaborone } \\
\text { Dam) }\end{array}$ & $\begin{array}{c}\text { Metsimotlhabe } \\
\text { River (Bokaa } \\
\text { Dam) }\end{array}$ \\
\hline POW & Power of soil moisture equation & 4.0 & 0.0 \\
\hline SL $(\mathrm{mm})$ & Soil moisture storage below which runoff occurs & 0.0 & 0.0 \\
\hline ST $(\mathrm{mm})$ & Maximum soil moisture capacity & 350 & 350 \\
\hline FT $(\mathrm{mm} / \mathrm{month})$ & Runoff from soil moisture at full capacity & 0.0 & 0.0 \\
\hline AI & Impervious catchment & 0.0 & 0.0 \\
\hline ZMIN (mm/month) & Minimum catchment's absorption rate & 42 & 50 \\
\hline ZMAX (mm/month) & Maximum catchment's absorption rate & 925 & 1500 \\
\hline PI (mm) & Interception storage & 2.0 & 1.5 \\
\hline TL (mm) & $\begin{array}{l}\text { Lag of runoff associated with that proportion of soil moisture storage } \\
\text { less than ground water runoff }\end{array}$ & 0.25 & 0.45 \\
\hline GL (month) & $\begin{array}{l}\text { Lag of runoff associated with that proportion of soil moisture storage } \\
\text { greater than ground water runoff }\end{array}$ & 0.0 \\
\hline R & Parameter defining evaporation-soil moisture storage relationship & 0.0 & 0.0 \\
\hline
\end{tabular}

